\title{
The Core Competitiveness Empirical Analysis on Small and Medium-sized Enterprises in China
}

\author{
Zhang Tingfa \\ School of Economics and Management \\ Qilu Normal University \\ Jinan, China \\ e-mail: ztfsdu2011@163.com \\ $\mathrm{Xu}$ Weishuang \\ School of Economics and Management \\ Qilu Normal University \\ Jinan, China \\ e-mail: xwsjn@163.com
}

\author{
Sun Peng \\ School of Economics and Management \\ Qilu Normal University \\ Jinan, China \\ e-mail: alexsp@163.com \\ Zhou Xinzhu \\ School of Economics and Management \\ Qilu Normal University \\ Jinan, China \\ e-mail: zhouxinzhu1980@163.com
}

\begin{abstract}
With the increasingly complex of the market competition environment, enterprise competition is increasingly fierce, more and more enterprises has realized the importance of innovation for enterprise survival and development. Currently, the development of SMEs is not optimistic, due to lack of sustainable development capacity, and the more prominent problem is the lack of core competitiveness. The paper researches the core competitiveness of SMEs by the empirical analysis, some conclusions are drawn.
\end{abstract}

Keywords-small and medium-sized enterprises (SMEs); core competitiveness; regression analysis; empirical analysis

\section{INTRODUCTION}

Only through technology innovation, the enterprise can apply new technology, new technology, new production methods to develop new products, reduce product cost and improve market share. Increasing investment in science and technology, seeking scientific and technological innovation and the pursuit of science and technology industrialization are the inevitable choice of market economy. Small and medium-sized enterprises of science and technology whose mission and survival means are mainly innovation have become an important force in economic development and small and medium-sized enterprises of science and technology play an indispensable role in science and technology industrialization. Compared with the traditional enterprises, small and medium-sized enterprises of science and technology whose characteristics are the typical intensive knowledge, high risk, and the high degree of innovation, the innovation and efficiency superior to other large and medium-sized enterprises. For example, $65 \%$ of the national invention patents, $82 \%$ of the new product development and $74 \%$ of technological innovation come from the small and medium-sized enterprise of science and technology. In China more than 50000 national high-tech enterprises account for more than $85 \%$. However, the high risk factors and uncertainty of small and medium-sized enterprise of science and technology in the process of converting technology to high-tech products, due to the new market, new technology, high-tech products of relatively immature, are in short life, which seriously restrict the development of small and medium-sized enterprise of science and technology and growth.

With the rapid development of information, knowledge and technology, more and more small and medium enterprises has realized that their long-term survival must rely on the core competencies and must bind building the scientific governance structure with improving the core competitiveness of enterprises in order to achieve longterm competitive advantage.

\section{THE CORE COMPETITIVENESS OF SMALL AND MEDIUM-SIZED ENTERPRISES}

With the further development of economic globalization, Chinese enterprises face the competition environment from the region to a globe gradually. In addition to the system reasons, the key lies in the core competitive force that is too weak to fail to really form the core competitiveness mechanism. How to improve enterprise overall quality and improve their ability of sustainable development has become the urgent subject. Only to constantly cultivate and enhance their core competitiveness can survive in the changing market environment and development.

\section{A. The characteristics of the core competitiveness of small and medium-sized enterprises}

(1)The core competence is not isolated, but is a part of the comprehensive competitiveness of enterprises. The 
enterprises competitiveness is a systematic organic combination of resources, capabilities and systems, in in which the combine core competitiveness is the special part and outstanding link and can not exist independently out of the system competitiveness.

(2)The core competitiveness has the value character, that is, the core enterprises competitiveness can make the core enterprises to improve the efficiency, reduce costs and create value better than the competitors, and can create more value for customers.

(3)The core competitiveness has a uniqueness, and is not easily imitated by competitors. The uniqueness of the enterprises core competitiveness not only determines the differences, but also determines the efficiency differences and income differences of the enterprises.

(4)The core competitiveness has certain scalability. The core competence is the cornerstone of the existing cooperations, the door leading to the future market. Therefore, the core competitiveness of enterprises can open the market and has an important role in promoting a product or service.

(5)The enterprises core competitiveness is dynamic. As the new business areas expand, the enterprises core competitiveness will generate, transfer and extinct in different segments of value chain activities.

\section{B. Elements of the core competitiveness of small and medium-sized enterprises}

(1) Technology Innovation

Technological innovation is the essential key factors in the creation and development of core competitiveness of small and medium-sized enterprises. The enterprises investment intensity in R \& D will affect the ability of technological innovation.

However, due to national insufficient attention to the small and medium enterprises in China, small scale, shortage of funds, the small and medium-sized enterprises is also faced with many problems in technological innovation, such as: inadequate funding; lack of research funding; serious lack of technology, personnel, information; high risks of technological innovation. These constraints have brought many difficulties for the technological innovation of small and medium-sized enterprises, but that the technology innovation can enhance the core competitiveness of small and medium-sized enterprises is an indisputable fact.

(2)Organizational Management

The organizational innovation has been largely changing along with the technical innovation, management innovation. It reflects the enterprise resources organization capabilities and management capabilities, and is the direct embodiment and the important content of the enterprises core competitiveness.

(3)Enterprise culture

Small and medium-sized enterprises in China has not a long history, at the same time, enterprise culture theory has entered into China for more than ten years, so, less small and medium-sized enterprises can clearly and systematically put forward their own enterprise culture. The experience of successful companies makes it more clear that a business should have own enterprise culture which has great significance for Chinese economic and social development in market economic conditions today.
(4)Integrity

Every factor among the composition elements of the core competitiveness contributes separately to enterprises value, but also forms a synergy force through the enterprise integration to contribute to enterprises value.

The enterprise is essentially an organizational system composed of resources and capacity, the effective integration of all kinds of resources is the foundation of the core competitive force.

\section{AN EMPIRICAL ANALYSIS OF THE CORE COMPETITIVENESS OF SMALL AND MEDIUM-SIZED ENTERPRISES}

\section{A. Sample selection and sample Source}

According to the data in the first half of 2006 in the sample database, the paper selects 46 small and medium enterprises in the manufacturing industries in Jiangsu Province, Shandong Province and Zhejiang Province in East China as the research sample.

\section{B. Hypothesis}

Hypothesis 1: the holding capacity of the largest shareholder and core competitiveness have a positive correlation;

Hypothesis 2: ownership concentration and the core competitiveness have a negative correlation;

Hypothesis 3: educated level of the general manager and the core competencies have a positive correlation;

Hypothesis 4: Two-level state is associated with the core competitiveness;

Hypothesis 5: the proportion of independent directors and the core competencies have a positive correlation;

Hypothesis 6: Board size is associated with the core competitiveness.

\section{Variable selection}

\section{1) Explained variables}

Based on the view at home and abroad, the core competence index system is summarized as follows:

(1) Technological innovation capability.

The $R \& D$ investment rate, the patents number is selected as the measurement index of technological innovation capability.

(2)Marketing development capabilities

The market expansion ability is the ability to open up the market, reflecting the competitiveness of the enterprise products in the market. It includes two indicators: market coverage and the market share.

(3)Business development capacity

Business development capacity includes the main business income rate and quick ratio.

\section{2) Explanatory variables}

(1) Ownership Structure

The paper selects the holding capacity of the largest shareholder and ownership concentration.

(2) Educated level of the general manager

Educated level of the general manager is divided into high school, junior college, undergraduate and master's degree or above, expressed by figures 1, 2, 3, 4 .

(3) Proportion of independent directors 
Proportion of independent directors is ratio of independent directors and all directors number.

(4) Two-level state

Accordance with the "dichotomy", as chairman and general manager is completely part-time, two-level state takes "1", otherwise takes "0 ", When chairman and general manager is part-time respectively, two-level state takes" $0.5 "$.

(5) Board size

In this paper, the number of company directors represents the board size.

\section{3) Control variables}

(1) Company size

This article will use the total assets of company size on a logarithmic

(2)Financial leverage
We use asset-liability ratio as a measure targets of financial leverage. Asset-liability ratio is ratio of total indebtedness and total assets.

\section{Research methods and models}

In this article, with SPSS software to analyze, this research will use the core competitiveness index as the dependent variable through regression analysis. Model is as follows formula 1:

where, ${ }^{{ }_{i j}}$ is the dependent variable, $a$ is constant item, $\varepsilon$ is random disturbance term, b and c represents estimated coefficients of the explanatory variables and control variables, other variables is shown in table 1 .

TABLE I. DEFINITION AND MEASUREMENT OF VARIABLES

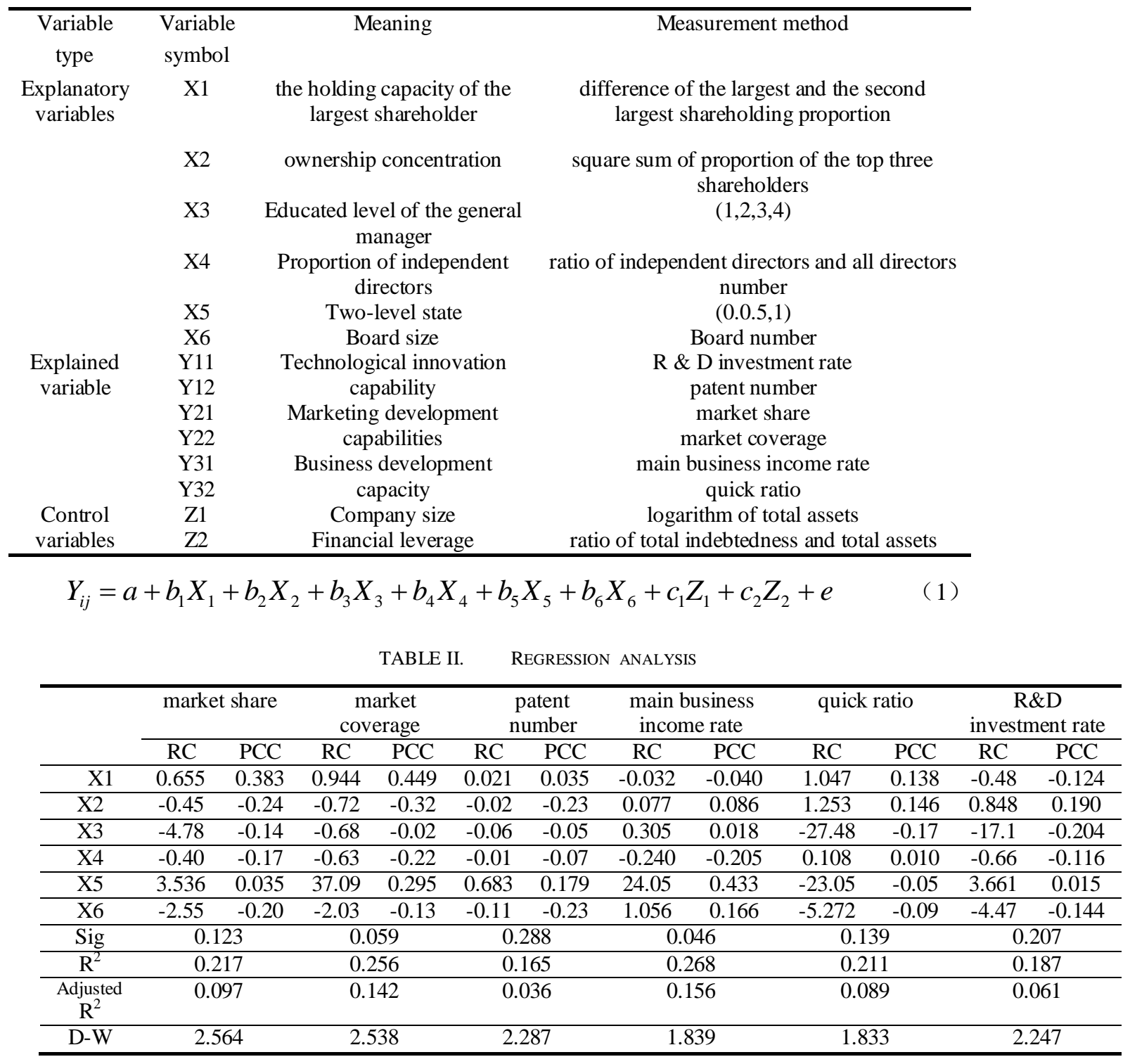




\section{REGRESSION ANALYSIS OF THE CORE COMPETITIVENESS OF SMALL AND MEDIUM-SIZED ENTERPRISES}

Where, RC: Regression coefficient; PCC: Partial correlation coefficient.

Based on regression results Table 2, the following conclusions can be drawn:

(1)The largest shareholder holding capacity is positive correlation with market share, market coverage and patents number, is not relevant with the main business income margin, quick ratio and $\mathrm{R} \& \mathrm{D}$ investment rate, which shows that the largest shareholder holding capacity has partial correlation with core competitiveness;

(2) Ownership concentration is negative correlation only with market coverage, not correlation with other core competence, which indicates that ownership concentration has partial correlation with core competitiveness;

(3) The educational level of general manager has no correlation with the core competitiveness, so assumptions 3 is not negated;

(4) The proportion of independent directors has no correlation with the core competitiveness, so assumptions 4 is not negated;

(5) Two-level state is only is positive correlation with the main business income margins, not correlated with other indicators, which two-level state has partial correlation with core competitiveness.

(6) The board size has no correlation with the core competitiveness, so assumptions 4 is not negated.

\section{CONCLUSIONS}

\section{A. The position of the knowledge economy is becoming more and more protruding}

Knowledge economy is the new economy on the basis of the information industry, software industry, consulting industry and other high-tech industry. In the era of knowledge economy, knowledge and information become the global resources of economic development directly.

\section{B. To be knowledge innovation breakthrough development bottleneck}

Under the impetus of the development of information and communication technology, To encourage small and medium-sized enterprises engaged in knowledge innovation, protect intellectual property rights protection will become more and more important.

\section{Knowledge innovation is the impulsion of the core competitiveness}

Innovation is the source of modern enterprises to maintain core competitiveness and the core of enterprise development strategy.

\section{Management idea innovation.}

Enterprise culture is the enterprise core competitive ability.

\section{E. Management innovation}

One is the construction of learning organization.The second is to accelerate the process of enterprise's informatization construction.

\section{REFERENCES}

[1] K Parikh. Sustainable development and low carbon growth strategy for India[J]. Energy, 2012, 40(1):31-38.

[2] Anne B., John P. U., Henning M. and Helle N..The Effect of Financial Factors on the Performance of New Venture Companies in High Tech and Knowledge-Intensive Industries: An Empirical Study in Denmark.[J], International Journal of Management,2003,(12): 535 547.

[3] Gary D. Resources of the firm, Russian high-technology startups, and firm growth[J].Journal of Business Venturing,2002,(17):533576.

[4] Ling-Feng H. and Yao-Tsung T., Technology Investment Mode of Innovative Technological Corporations: $\mathrm{M} \& \mathrm{~A}$ Strategies Intended to Facilitate Innovation[J], The Journal of American Academy of Business, Cambridge, March 2005: 185 186.

[5] M. Kamil K., Dolun Ö., and Onur Ö.. Growth Plans of Small Businesses in Turkey: Individual and Environmental Influences[J].Journal of Small Business Management,2006,44(1):114-129.

[6] Michael L.H.,Shanan G. Gibson. Determining the Common Problems of Early Growth Small Businesses in Eastern North Carolina[J]SAM Advanced Management Journal,Spring2006:3945.

[7] Penrose E., Theory of the Growth of the Firm[M], Oxford:Oxford UniversityPress, 1995.

[8] Robert E. Carpenter and Bruce C. Petersen. Is the Growth of Small Firms Constrained by Internal Finance?[J].The Review of Economics and Statistics, May 2002, 84(2): 298-309

[9] Thorsten B, Asli D and Vojislav M. Financial and Legal Constraints to Growth: Does Firm Size Matter?[J] The Journal Of Finance Vol Lx, NO. 1 February 2005, 137 171.

[10] Rhee, J., Park, T., Lee, D. H. Drivers of Innovativeness and Performance for Innovative SMEs in South Korea: Mediation of Learning Orientation[J]. Technovation, 2010, 30 (1): 65-75. 